\title{
PROBLEMATIKA SISTEM PEMBELAJARAN SALAFIYAH DI PONDOK PESANTREN SHUFFAH HIZBULLAH DUSUN OLI DESA DESA HITU KABUPATEN MALUKU TENGAH
}

\author{
Saida Manilet \\ IAIN Ambon \\ saida.manilet@iainambon.ac.id
}

\begin{abstract}
The purpose of this study was to obtain information regarding the salafiyah learning system in the Shuffah Hizbullah Islamic boarding school along with the basic problems that resulted in the community of Oli hamlet not involving their children in the system. This type of research is ex post facto with a qualitative approach. In this study, the data collection techniques used were observation, interview and documentation. The data is then reduced according to the focus of the study, after which it is presented in a narrative form and ends with drawing conclusions. The results of the study found that the salafiyah learning system in Dusun Oli, Hitu Village, Leihitu District still uses classical models and methods that have not been touched by modern things. However, the evaluation to measure the success of the objectives has not been carried out properly. In addition, the people of Dusun Oli generally like learning salafiyah, but what is a factor in the participation of students from Hamlet Oli in learning salafiyah is due to 5 things, namely 1) Parents' lack of understanding about salafiyah subjects and the benefits of learning them. This is because there is no clear socialization from the pesantren, 2) The opportunity to become the TNI that was promised by the pesantren to ordinary students other than boarding students causes parents to feel sufficient if their child only studies at the madrasa in the morning, 3) Parents' busyness causes the child participate in helping their work, 4) There is no obligation given to all students in the Islamic Boarding School to take part in salafiyah lessons, 5) Lack of parental trust to allow children to study in the pesantren in the afternoon and evening.
\end{abstract}

Keywords: Salafiyah learning system, view of Dusun Oli community

\begin{abstract}
Abstrak: Tujuan penelitian ini adalah untuk memperoleh informasi terkait sistem pembelajaran salafiyah di pondok pesantren Shuffah Hizbullah beserta masalah dasar yang mengakibatkan masyarakat dusun Oli tidak melibatkan anak mereka dalam sistem tersebut.Tipe penlitian ini adalah ex post facto dengan pendekatan kualitatif. Dalam penelitian ini teknik pengumpulan data yang digunakan adalah observasi, wawancara dan dokumentasi. Data kemudian direduksi sesuai fokus penelitian, setelah itu disajikan dalam bentuk narasi dan berakhir dengan penarikan kesimpulan. Hasil penelitian ditemukan bahwa sistem pembelajaran salafiyah di Dusun Oli Desa Hitu Kecamatan Leihitu masih menggunakan model dan metode klasik yang belum tersentuh oleh hal-hal yang modern. Namun evaluasi untuk mengukur keberhasilan tujuan belum terlaksana sebagaimana meskinya. Selain itu yang masyarakat Dusun Oli pada umumnya menyukai pembelajaran salafiyah, namun yang menjadi faktor ketidakikutsertaan siswa dusun Oli dalam pembelajaran salafiyah diakibatkan karena 5 hal, yakni 1) Ketidak pahaman orang tua tentang mata pelajaran salafiyah dan manfaat mempelajarinya karena tidak ada sosialisasi yang jelas dari pihak pesantren, 2) Peluang menjadi TNI yang diberikan pihak pesantren kepada siswa biasa selain santri mondok menyebabkan orang tua merasa cukup belajar di madrasah di pagi hari, 3) Kesibukan orang tua yang menyebabkan turut serta bantuan anak dalam pekerjaan, 4) Tidak adanya kewajiban yang diberikan Pondok Pesantren kepada semua siswa untuk mengikuti pembelajaran salafiyah 5) Kurangnya kepercayaan orang tua untuk mengizinkan anak pulang pergi belajar di pesantren sore dan malam.
\end{abstract}

Kata Kunci: Sistem pembelajaran salafiyah, pandangan masyarakat Dusun Oli 


\section{PENDAHULUAN}

Pondok pesantren merupakan salah satu dari sebuah lembaga pendidikan Islam yang tertua di Indonesia (Yatim, 2010: 309). Sejak berdirinya, pondok pesantren telah mengalami banyak perubahan dan memainkan berbagai macam peran di Indonesia hingga saat ini. Peran tersebut antara lain sebagai lembaga pendidikan dan pengajaran Islam, lembaga perjuangan dan dakwah islamiyah, dan lembaga pemberdayaan dan pengabdian masyarakat (Muhakamurrohman, 2014: 109-118).

Pondok pesantren atau "tempat tinggal para santri" (Dhofier, 2997: 18), dalam hal ini pondok pesantren kombinasi (Ghazali, 2001: 15), selain terjadi proses pembelajaran di kelas, ada beberapa tradisi yang biasanya terjadi dalam pesantren, seperti tradisi rihlah ilmiah, meneliti, menulis kitab, membaca kitab kuning, menghafal dan tradisi keagamaan lainnya (Nata, 2016: 67-75). Dengan demikian maka sudah barang tentu akan berbeda out put yang dihasilkan oleh sekolah dan madrasah dan out put yang dihasilkan oleh pondok pesantren. Oleh karena itu, kehadiran pondok pesantren di tengah masyarakat menjadi suatu keniscayaan.

Kehadiran pondok pesantren menjadi harapan masyarakat dalam membentuk generasi masa depan yang syarat akan moral keislaman (Mastuhu, 1994: 55). Dengan kompleksnya permasalahan yang dihadapi oleh masyarakat saat ini, justru kehadiran pesantren menjadi solusi di tengah-tengah kegamangan lembaga pendidikan lainnya. Dengan demikian, maka kehadiran pesantren bukan untuk mengabaikan aspirasi masyarakat, namun hadir untuk menghidupkan potensipotensi dasar yang telah dimiliki oleh masyarakat, pesantren melanyelenggarakan pendidikannya untuk melanggengkan nilai-nilai yang hidup dalam masyarakat itu sendiri. Dengan keikutsertaan masyarakat dalam pengelolaan pendidikan pesantren, maka akan memberikan fungsi pendidikan yang berakar dari masyarakat (Wekke: 2012, 205-226).

Pondok pesantren Shuffah Hizbullah adalah salah satu pondok pesantren yang terletak di Dusun Oli Desa Hitu kecamatan Leihitu yang berdiri sejak tahun 1999. Dalam perjalanannya selama hampir 20 tahun rupanya belum menuai 
harapan yang maksimal. Kehadiran pondok pesantren yang bertujuan mempertahankan nilai-nilai akhlak alkarimah dalam menghadapi masifnya globalisasi dan westernisasi belum direspon oleh masyarakat, terutama masyarakat tempat didirikannya lembaga ini, yakni masyarakat Dusun Oli yang kebanyakan menyekolahkan anaknya di sini justru anaknya tidak mengikuti keseluruhan program salafiyah.

Dalam pengamatan, ditemukan bahwa siswa yang berasal dari Dusun Oli hanya mengikuti program khalafiyah saja sama halnya anak madrasah. Mereka tidak mengikuti program salafiyah pesantren seperti tahfiz Al-Qur'an, belajar kitab kuning, belajar bahasa Arab dan lain sebagainya. Meski sudah disediakan opsi sendiri oleh pihak pesantren "tidak perlu mondok dan membayar uang makan, yang penting bisa mengikuti program pesantren", namun orang tua tetap tidak mendukung. Bahkan pengajian mingguan dan bulanan yang diadakan pesantren juga jarang sekali diikuti oleh orang tua dari masyarakat Dusun Oli. Ini menampakkan bahwa masyarakat belum menaruh kepercayaan pada pesantren serta menunjukkan dukungan dan apresiasi atas hadirnya lembaga ini. Kenyataan demikian menjadi penting untuk diteliti bagaimana sistem pembelajaran salafiyah di pondok pesantren Shuffah Hizbullah di Dusun Oli Kecamatan Leihitu Kabupaten Maluku Tengah, sehingga dapat memberi kontribusi bagi pihak pondok maupun masyarakat sekitar.

\section{A. Metode Penelitian}

Penelitian ini menggunakan tipe penelitian expost facto (Arikunto, 2010: 17), dengan pendekatan kualitatif (Sukmadinata, 201: 36). Yakni mengumpulkan datadata yang telah ada di lapangan dengan menulis dan mendiskripsikan secara kualitatif tentang sistem pembelajaran salafiyah di pondok pesantren Shuffah Hizbullah dan pandangan masyarakat tentang sistem tersebut.

Sumber data primer dalam penelitian meliputi pimpinan pondok pesantren, pengajar salafiyah, santri yang mengikuti pembelajaran salafiyah, alumni yang mengikuti pembelajaran salafiyah, dan masyarakat Dusun Oli yang anaknya sekolah di pondok pesantren Shuffah Hizbullah sebagai informan kunci dan informan pendukung meliputi Kepala Dusun Oli dan Kepala Negeri Hitu. Sedangkan sumber 
data sekunder meliputi dokumen-dokumen yang terkait keadaan santri, keadaan pengajar, uku-uku yang mendukung teori dalam penelitian ini.

Teknik pengumpulan data meliputi teknik oservasi dengan melihat kondisi jalannya sistem pembelajaran salafiyah, teknik wawancara untuk menemukan informasi dari informan kunci dan pendukung tentang sistem pembelajaran salafiyah beserta kekurangan dan keleihannya, dan teknik dokumentasi, yakni mengumpulkan dokumen-dokumen penting terkait sistem pemelajaran salafiyah.

Teknik analisis data dilakukan dengan menggunakan model Miles dan Huberman yang menyatakan bahwa aktivitas dalam analisis data kualitatif dilakukan secara interaktif dan berlangsung secara terus menerus hingga tuntas hingga data mencapai titik jenuh (Sugiyono, 2010: 91) analisis ini dilakukan dengan tahapan sebagai berikut:

1. Reduksi data, yakni analisis untuk memilih, memfokuskan, menyederhanakan, mengabstraksikan, serta mentransformasikan data yang didapat dari catatan lapangan. Hasil reduksi data ini, maka hal-hal yang sesuai dengan fokus penelitian akan diambil, sedangkan yang tidak sesuai dengan fokus akan dibuang (Trianto, 2011: 287). Reduksi data dilakukan oleh peneliti setelah melakukan wawancara dengan informan. Dari hasil wawancara itu, penulis mengambil hal-hal yang berkaitan dengan sistem pembelajaran salafiyah, dan mebuang hal-hal yang dianggap tidak menyentuh fokus kajian ini.

2. Display daya/penyajian data, yakni langkah analisis dalam bentuk membuat narasi, bagan, hubungan, antar katergori dan lain sebagainya. Proses analisis ini adalah menampilkan data lapangan dan membuat hubungan antar fenomena untuk menemukan makna apa yang sebenarnya terjadi dan tindakan ayang perlu diambil selanjutnya untuk mencapai tujuan penelitian berdasarkan apa yang dipahami. dalam tahap ini penulis menyajikan data-data lapangan dan menguhubungkannya dengan fenomena yang ada.

3. Verifikasi data, yakni penarikan kesimpulan. Analisis ini dilakukan untuk mendapatkan bukti-bukti dari kesimpulan awal yang masih bersifat sementara. Jika kesimpulan awal didukung oleh bukti-bukti yang akurat dengan kondisi saat peneliti di lapangan, maka kesimpulan yang diperoleh adalah kesimpulan 
yang kredibel. Dalam penarikan kesimpulan, penulis membuat kesimpulan yang bersifat terbuka, baik dari hasil observasi, wawancara, dan dokumentasi.

\section{HASIL}

\section{Sistem Pembelajaran Salafiyah Di Pondok Pesantren Shuffah Hizbullah Dusun Oli desa Hitu kecamatan Leihitu Kabupaten Maluku Tengah}

Sistem pembelajaran terdiri dari beberapa komponen, yakni tujuan, materi, metode, media dan evaluasi pembelajaran. Adapun hasil penelitian terkait komponen sistem pembelajaran salafiyah di pondok pesantren Shuffah Hizbullah diuraikan sebagai berikut:

\section{Tujuan Pembelajaran Salafiyah}

Secara keseluruhan dalam pengamatan peneliti, segala sesuatu yang berkaitan dengan pembelajaran salafiyah di pondok pesantren Shuffah Hizbullah tidak tertulis secara administratif, mulai dari perencanaan pembelajaran hingga evaluasinya tidak dilakukan secara tertulis, namun hanya sebatas penyampaian lisan antara ustaz dan para santri.

Dari hasil wawancara dengan pimpinan pesantren ditemukan bahwa tujuan pembelajaran salafiyah antara lain sebagai berikut:

a. Agar santri dapat membaca dan menghafal AI-Qur'an dengan baik dan benar minimal 3 juz

b. Agar santri dapat memahami masalah pokok ibadah dan muamalah dan menghafal minimal 40 hadits

c. Agar santri dapat mengetahui dasar-dasar tata bahasa Arab dengan menghafal minimal 1 kitab nahwu atau sharaf

Ketiga poin tersebut merupakan tujuan utama sistem pembelajaran salafiyah di pondok pesantren Shuffah Hizbullah dusun Oli desa Hitu kecamatan Leihitu. Sementara tujuan pendukung lainnya adalah:

a. Agar santri memiliki kecakapan dalam berpidato

b. Agar santri dapat menguasai ilmu seni bela diri

\section{Materi pembelajaran}


Dari paparan tujuan pembelajaran salafiyah di atas, maka materi pembelajaran salafiyah di pondok pesantren Shuffah Hizbullah meliputi:

a. Pembelajaran Al-Qur'an

Pembelajaran Al-Qur'an di sini bukan berarti mengkaji isi Al-Qur'an beserta tafsirannya, namun materi pembelajaran AI-Qur'an yang ada di pondok pesantren Shuffah Hizbullah adalah tentang tata bacaan Al-Qur'an meliputi hukum bacaan (ilmu tajwid) dan pengucapan huruf (makharijul huruf) sekaligus menghafalnya. Pembelajaran ini dilakukan dengan alasan bahwa rata-rata santri yang masuk di pondok pesantren belum dapat membaca Al-Qur'an dengan baik dan benar. Karena itu, pembelajaran ini merupakan hal utama dalam sistem pembelajaran salafiyah.

b. Pembelajaran Hadits

Materi pembelajaran hadits meliputi hadits-hadits terkait ibadah sehari-hari, yakni tharah, salat, dan materi terkait muamalah seperti pengurusan jenazah dan lain sebagainya serta materi terkait sifat-sifat terpuji, seperti ikhlas, sabar, tawakkal, dan lain-lain. Materi ini diberikan kepada santri dengan pertimbangan bahwa masih banyak di antara santri yang masuk ke pondok pesantren belum memahami dengan benar beberapa masalah tersebut.

Selain pertimbangan di atas, para santri sebagaimana yang penulis deskripsikan pada bagian kegiatan santri di pesantren, mereka sebelumnya tidak terbiasa untuk melaksanakan salat, mengaji, berperilaku kasar, dan seagainya. Ini menunjukkan bahwa pilihan pimpinan pesantren untuk mengajarkan dasar-dasar ibadah pada pembelajaran hadits di atas menjadi tepat, karena sesuai keadaan santri.

c. Pembelajaran Nahwu dan Sharaf

Pada pembelajaran ini materi yang diajarkan adalah ilmu tata bahasa Arab, yakni tentang kalam dan pembagiannya seperti isim dan fi'il, i'rab dan bagiannya yakni rofa', nashob, harfujjer, dan jazm serta amil-amil untuk pembelajaran nahwu, sedangkan materi sharaf tentang tashrif, ishtilahi dan sebagainya. Materi ini diberikan dengan pertimbangan bahwa ilmu dasar tata bahasa Arab ini belum dipelajari santri, karena semua santri yang belajar di sini datang dari latar belakang 
sekolah umum dan madrasah. Materi ini diajarkan pada hari kamis dan jumat setelah salat asyar di ruang kelas. Santri yang belajar di pondok pesantren baik wustha maupun aliyah, sama-sama mempelajari nahwu sharaf dari materi dasar tersebut. Namun terpisah kelasnya masing-masing.

Jadwal belajar salafiyah dapat diamati pada tabel berikut:

Tabel 1. Jadwal pembelajaran salafiyah

\begin{tabular}{|c|c|c|}
\hline MATA PELAJARAN & HARI & WAKTU \\
\hline Tahfidz Al-Qur'an & \multirow{3}{*}{ Senin } & Ba'da Subuh \\
\hline Hadits & & Ba'da Asar \\
\hline Tahsin Al-Qur'an & & Ba'da Magrib \\
\hline Tahfidz Al-Qur'an & \multirow{4}{*}{ Selasa } & Ba'da Subuh \\
\hline Hadits & & Ba'da Asar \\
\hline Tahsin Al-Qur'an & & Ba'da Magrib \\
\hline Muhadharah & & Ba'da Isya \\
\hline Tahfidz Al-Qur'an & \multirow{3}{*}{ Rabu } & Ba'da Subuh \\
\hline Karate dan Silat & & Ba'da Asar \\
\hline Tahsin Al-Qur'an & & Ba'da Magrib \\
\hline Tahfidz Al-Qur'an & \multirow{3}{*}{ Kamis } & Ba'da Subuh \\
\hline Nahwu Sharaf & & Ba'da Asar \\
\hline Tahsin Al-Qur'an & & Ba'da Magrib \\
\hline Tahfidz Al-Qur'an & \multirow{4}{*}{ Jumat } & Ba'da Subuh \\
\hline Nahwu Sharaf & & Ba'da Asar \\
\hline Tahsin Al-Qur'an & & Ba'da Magrib \\
\hline Muhadharah & & Ba'da Isya \\
\hline Tahfidz Al-Qur'an & \multirow{3}{*}{ Sabtu } & Ba'da Subuh \\
\hline Karate dan Silat & & Ba'da Asar \\
\hline Tahsin Al-Qur'an & & Ba'da Magrib \\
\hline
\end{tabular}

Dari hasil wawancara di atas, dapat dikatakan bahwa meskipun pembelajaran salafiyah hanya berfokus pada pembelajaran AI-Qur'an, hadits, dan nahwu sharaf, namun kegiatan pendukung diberi porsi waktu yang sama dengan kegiatan inti pembelajaran salafiyah.

\section{Metode pembelajaran}

Metode pembelajaran salafiyah ditemukan dari hasil wawancara dan observasi sebagai berikut:

a. Metode yang digunakan dalam pembelajaran Al-Qur'an di pondok pesantren yakni metode demonstrasi dan metode hafalan. Metode demonstrasi yang dimaksud adalah santri mendemonstrasikan bacaan AI-Qur'an di hadapan ustaz 
kemudian diamati hukum bacaan dan makharijul hurufnya. Ketika terjadi kesalahan dalam bacaan, ustaz memperbaiki dan santri mengikuti serta mengulang hingga benar bacaannya. Sedangkan metode hafalan adalah santri menghafal beberapa ayat al-Qur'an kepada ustaz setiap hari setelah salat subuh. Dalam pembelajaran Al-Qur'an ini, saat menghafal Al-Qur'an, santri terlebih dahulu menulis ayat yang hendak disetorkan kepada ustaz pada buku catatan mereka. Saat menyetorkan hafalan, santri terlebih dahulu menunjukkan tulisan ayat yang ada pada buku catatannya kemudian mulai menghafal ayat tersebut. Tulis menulis ayat pada buku catatan sebelum menghafal ini dimaksudkan agar selain membantu santri dalam mengingat ayat, juga membekali santri agar lancar menulis Arab.

b. Metode pembelajaran hadits ialah model wetonan, yakni ustaz duduk di depan di tempat yang agak tinggi dan mengajarkan santri tentang isi kitab. Pembelajaran hadits disampaikan dengan metode ceramah dan tanya jawab. Dalam proses pembelajaran, Ustaz membaca kitab, menerjemahkan dan menjelaskan maknanya, sementara santri menandai arti pada masing-masing kitabnya. Setelah itu, santri disuruh membaca ulang dan menjelaskan sesuai pemahamannya. Ketika terjadi kesalahan dalam menjelaskan, maka sang ustaz memperbaiki kesalahan tersebut. Di akhir pembelajaran, santri ditugaskan menghafal hadits tersebut.

c. Metode Pembelajaran Nahwu dan Sharaf

Metode yang digunakan dalam proses pembelajaran nahwu sharaf biasanya adalah metode bendongan, hafalan, latihan, dan penugasan. Dalam proses pembelajaran, ustaz membaca per baris dan diikuti oleh santri secara berulangulang hingga setengah hafal, setelah itu ustaz artikan dan jelaskan makna per bait beserta contohnya. Santri menandai arti pada kitabnya masing-masing dan menulis contoh yang diberikan ustaz.

Pada akhir pembelajaran santri biasanya diberi tugas terkait meteri yang barusan diajarkan sebagai latihan di asrama. Tugas tersebut hanya sebatas latihan semata, tidak diperiksa kembali kesalahan atau kebenarannya lagi oleh ustaz.

\section{d. Media/Bahan/Alat pembelajaran}


Dari hasil pengamatan peneliti terkait kitab yang dijadikan sebagai bahan dalam pembelajaran Al-Qur'an hanyalah Al-Qur'an Al-Karim saja. Sebab yang diajarkan hanya terkait tajwid dan makhrijul huruf. Sedangkan pada pembelajaran hadits, pondok pesantren Shuffah Hizbullah menggunakan media kitab kuning yakni kitab Riyadhusshalihin dan kitab Bulughul Maram. Kitab yang dipegang ustaz adalah kita kuning (kita gundul), sedangkan yang dipegang santri adalah kitab yang sudah ada syakalnya dan memegang pensil, sehingga dalam pembelajaran santri hanya menandai arti pada kitabnya masing-masing. Untuk pembelajaran nahwu sharaf selain menggunakan kitab Jurumiyah dan Amsilatuttasrifiyah, ustaz juga menggunakan papan tulis dan spidol untuk menulis contoh-contoh.

Dalam proses pembelajaran salafiyah, pondok pesantren Shuffah Hizbullah belum sedikitpun menggunakan media berbasis teknologi, misalkan infocus, media audio visual, dan sebagainya. Proses pembelajaran masih murni menggunakan sistem pembelajaran klasik yang tidak tersentuh alat-alat modern.

\section{Evaluasi pembelajaran}

Pada dasarnya ada waktu-waktu yang ditentukan untuk melakukan evaluasi pembelajaran salafiyah. Hanya saja waktu yang ditentukan tersebut belum dijalankan secara konsisten oleh pondok pesantren Shuffah Hizbullah untuk menilai keberhasilan santri mengikuti pembelajaran salafiyah. Pembelajaran dilakukan secara rutin namun tidak ada waktu evaluasi serta model evaluasi yang paten dan terjadwal sebagaimana evaluasi tengah semester dan akhir semester pada pembelajaran khalafiyah. Persyaratan standar kelulusan belajar salafiyah hanya disampaikan secara lisan saja pada saat pertemuan pertama dalam pembelajaran.

a. Evaluasi dari pembelajaran hadits, santri diberi standar menghafal minimal 40 hadits sampai selesai dari pesantren. Entah santri tersebut mulai masuk dari tingkat wustho (setingkat MTs) maupun yang masuk pada tingkat Aliyah. Yang terpenting dari pembelajaran hadits ini adalah santri mampu memahami isi hadits dan mengaplikasikan dalam kehidupan sehari-hari. Penekanan pembelajaran ini tidak diarahkan pada kecakapan membaca kitab kuning, namun hanya sebatas memahami saja. Hal ini dilakukan dengan alasan bahwa waktu yang digunakan untuk belajar hadits cukup terbatas. Waktu untuk mempelajari hadits hanya dua hari dalam seminggu dengan durasi waktu kurang lebih 2 jam, yakni setelah salat 
asyar hingga menjelang magrib, sekitar pukul 16.00-18.00. Sehingga 1 minggu hanya 4 jam belajar saja. Selain itu kitab yang tersedia di sini tidak banyak yang kitab gundul, namun kebanyakan sudah memiliki syakal. Waktu evaluasi hafalan hadits yang direncanakan oleh pondok pesantren sebenarnya setiap tahun sebelum ramadhan, namun hal ini belum berjalan secara rutin.

b. yang diberikan adalah santri mampu menghafal salah satu dari kitab jurumiyah atau amsilatuttasrifiyah. Akan tetapi standar ini belum pernah diberlakukan kepada santri hanya saja ada evaluasi yang dilakukan setiap semester untuk menilai pemahaman santri terkait materi yang telah diajarkan.

c. Evaluasi pembelajaran Al-Qur'an untuk mengecek bacaan santri dilakukan setiap hari setelah salat magrib melalui demonstrasi bacaan AI-Qur'an seperti yang telah diuraikan sebelumnya. Sedangkan evaluasi hafalan dilakukan juga setiap hari setelah salat subuh melalui setoran hafalan AI-Qur'an oleh semua santri secara perorangan. Terget akhir dari kegitan menghafal AI-Qur'an ini adalah santri harus menghafal minimal 3 juz sampai lulus dari pondok pesantren. Khusus program ini, setiap bulan ada kegiatan simaan bersama. Yakni santri dibentuk berkelompok yang terdiri dari 4-5 orang duduk melingkar dalam lingkaran kecil kemudian saling menyetorkan semua ayat Al-Qur'an yang telah dihafal. Satu santri menghafal, dan santri lainnya menyimak. Ketika terjadi kesalahan dalam hafalan langsung diperbaiki teman sekelompoknya. Ini dilakukan secara bergiliran hingga semua orang dalam kelompok itu selesai menyetor hafalannya. Kegiatan simaan bersama ini didampingi oleh para ustaz. Tidak ada waktu tertentu untuk mengevaluasi bahwa santri telah mencapai 3 juz. Bahkan santri yang menghafal kurang dari atau lebih dari taerget yang ditetapkan tidak dievaluasi. Hanya saja pada bulan ramadhan, santri diberi tugas secara bergiliran untuk menghafal AlQur'an di hadapan teman-temannya per juz.

Dari uraian evaluasi ini dapat disimpulkan bahwa standar capaian pembelajaran salafiyah di pondok pesantren Shuffah Hizbullah sebenarnya ada dalam perencanaan pimpinan pondok pesantren, meski perencanaan itu tidak tertulis. Hanya saja perencanaan tersebut belum dilaksanakan secara maksimal. Sehingga tujuan yang dinginkan dari pembelajaran salafiyah tidak terukur secara pasti keberhasilannya pada santri. 
Pelaksanaan evaluasi yang kurang maksimal ini disebabkan karena lulusan pondok pesantren Shuffah Hizbullah tidak mendapatkan ijazah dari pembelajaran salafiyah. Yang didapat hanyalah ijazah madrasah. Sehingga lulusan dari sini kesannya sama dengan lulusan madrasah pada umumnya.

\section{Hasil Pembelajaran Salafiyah di Pondok Pesantren Shuffah Hizbullah Dusun Oli Desa Kecamatan Leihitu Kabupaten Maluku Tengah}

Hasil pembelajaran salafiyah menurut para alumni selain bermanfaat bagi diri sendiri, ilmu yang didapatkan juga bermanfaat dalam dunia kerja mereka. Lulusan pesantren di lingkungan TNI diperioritaskan menjadi binroh bagi teman-teman anggota TNI yang lain. Di sekolah, alumni pondok pesantren yang menjadi guru tidak hanya menggunakan ilmunya saat mengajar agama, namun bisa menjadi pembimbing rohani juga bagi siswa di sekolah. Selain itu juga alumni dapat merasakan manfaat pembelajaran salafiyah sehingga dapat membuka taman pengajian Al-Qur'an dan komunitas Bahasa di kampung halaman sebagai pengabdian bagi masyarakat daerah asalnya.

Dari hasil wawancara juga dapat disimpulkan bahwa ternyata kemampuan hafalan baik Al-Qur'an maupun hadits antara satu santri dengan santri yang lainnya berbeda-beda, ada yang menghafal hingga 7 juz (melebihi target), dan ada yang menghafal tidak sampai 3 juz. Begitu pula dengan jumlah hadits yang dihafal. Ada yang menghafal hingga 140 hadits dan ada yang tidak cukup 10 hadits. Ini menandakan bahwa tidak ada penekanan untuk mencapai 3 Juz Al-Qur'an dan 40 hadits selama belajar di pondok pesantren.

Dari alumni pondok pesantren peneliti menemukan data bahwa sejak tahun 2000 hingga 2020 ini, sistem pembelajaran salafiyah masih sama. Materi ajar yang diajarkan masih sama yakni seputar hadits dan ilmu nahwu sharaf. Hanya saja jika dahulu hadits hanya dipelajari dari kitab bulughul maram, sekarang sudah ditambah lagi dengan kajian kitab riyadhushalihin. Penilaian yang dilakukan dalam pembelajaran salafiyah juga sama, tidak dinilai sejauh mana santri menghafal AlQur'an dan hadits serta tidak mengukur kemampuan santri dalam mengimla' AlQur'an. Hal ini sebagaimana yang dikemukakan oleh alumni pada paparan evaluasi pembelajaran salafiyah yang lalu. 
Meskipun ada banyak manfaat yang dirasakan alumni pondok pesantren dari pembelajaran salafiyah, namun menurut mereka sistem pembelajaran salafiyah di pondok pesantren masih perlu dikembangkan dan diperbaiki lagi sistemnya, terutama dalam bidang kitab kuning dan nahwu sharaf. Tujuan pembelajaran hadits yang ditekakankan pada pemahaman dan hafalan sebaiknya ditingkatkan lagi pada kemampuan membaca kitab kuning. Sedangkan ilmu nahwu sharaf yang memberi bekal pada kemampuan menyusun kalimat bahasa Arab ditingkatkan lagi dengan kemampuan berbahasa Arab. Apalagi berdasarkan hasil wawancara dengan pengajar di pondok pesantren, bahwa semua pengajar sebenarnya mampu berbahasa Arab.

Jika demikian, berarti ada potensi besar untuk mengajak santri berkomunikasi dengan menggunakan bahasa Arab. Apalagi dalam kesehariannya di asrama, santri diwajibkan menghafal 5 kosa kata bahasa Arab dan Bahasa Inggris beserta artinya sebelum tidur 3 kali dalam seminggu.

\section{Pandangan Masyarakat tentang Sistem Pembelajaran Salafiyah di Pondok Pesantren Shuffah Hizbullah}

Pandangan masyarakat dalam penelitian ini adalah tentang pendapat masyarakat terkait sistem pembelajaran salafiyah di pondok pesantren Shuffah Hizbullah yang telah berdiri selama hampir 20 tahun. Berdasarkan hasil wawancara dengan masyarakat, ternyata mereka memandang pentingnya belajar agama, terutama masalah salat dan mengaji (membaca Al-Qur'an) dan itu semua ada dalam program salafiyah pesantren. Selain pentingnya belajar agama ada juga program pesantren untuk menghafal Al-Qur'an, para orang tua juga sangat menyukai program tersebut, hanya saja pihak pesantren tidak mewajibkan program itu kepada setiap anak yang masuk ke pesantren. Di sisi lain mereka tidak mengetahui apa saja yag diajarkan dalam sistem pembelajaran salafiyah. Orang tua tidak tahu apa itu belajar hadits, belajar bahasa arab, mereka tidak tahu belajar tentang hal itu. Yang mereka ketahui selain belajar di madrasah hanya ada karate, itupun tidak semua orang tua mengetahuinya.

Masyarakat sebenarnya tidak tahu persis apa saja yang dipelajari dalam sistem pembelajaran salafiyah. Yang diketahui di pesantren tentang belajar sore 
hanyanyalah kegiatan karate. Selain dari pada kegiatan tersebut, masyarakat dusun Oli tidak tahu. Hal itu terjadi karena menurut mereka pondok pesantren tidak pernah memberitahukan masyarakat tentang program apa saja ada dalam sistem pembelajaran salafiyah.

Selain itu, sejauh ini pondok pesantren belum sekalipun melakukan koordinasi dengan masyarakat dusun Oli terkait program yang dijalankan di pondok pesantren, sehingga belum ada upaya dan kerja sama masyarakat dalam mendukung program pesantren. Hal ini sebagaimana disampaikan sendiri oleh Kepala dusun Oli kecamatan Leihitu.

Uraian pernyataan kepala dusun menunjukkan bahwa selama berdirinya pondok pesantren di dusun Oli desa Hitu kecamatan Leihitu belum pernah mengadakan koordinasi terkait program pembelajaran salafiyah dengan masyarakat dusun Oli tempat berdirinya lembaga ini. Sehingga masyarakat tidak mengetahui tentang masalah tersebut dan tidak mengambil langkah-langkah untuk mendukung program tersebut. Meskipun pihak pondok pesantren sering diundang untuk ceramah pada hari-hari besar keagamaan, khotbah di hari jumat, akan tetapi pihak pesantren tidak pernah menyampaikan program pembelajaran salafiyah kepada masyarakat dusun Oli beserta tokoh masyarakatnya.

Selanjutnya dalam pandangan kepala dusun Oli, penyebab tidak adanya koordinasi dan kerja sama yang baik dengan masyarakat, dari 100\% anak-anak Dusun Oli, hanya $40 \%$ persen yang sekolah di pesantren, yang lainnya sekolah di tempat lain yang lokasinya cukup jauh dari dusun Oli.

Selain tidak adanya koordinasi dengan masyarakat dusun Oli, kehadiran pondok pesantren di desa Hitu dirasa belum berbaur dengan masyarakat di daerah ini. Hal ini ditemukan dari pernyataan kepala desa Hitu bahwa kehadiran pondok pesantren di desa Hitu belum dekat dengan masyarakat, belum berbaur dengan budaya masyarakat, sehingga pondok pesantren tidak terasa kehadirannya di negeri ini. Hal ini menjadi satu penyebab pondok pesantren tidak begitu dikenal dekat oleh masyarakat. 


\section{Faktor Penyebab Masyarakat Dusun Oli Tidak Mengikutkan Anaknya dalam Sistem Pembelajaran Salafiyah di Pondok Pesantren Shuffah Hizbullah}

Dari hasil wawancara yang penulis dapatak terkait hal ini, dapat disimpulkan bahwa faktor penyebab masyarakat tidak mengikutkan anaknya dalam pembelajaran salafiyah adalah karena:

1. Ketidak pahaman orang tua tentang mata pelajaran salafiyah dan manfaat mempelajarinya karena tidak ada sosialisasi yang jelas dari pihak pesantren

2. Pesantren tidak mewajibkan pembelajaran salafiyah kepada semua siswa yang sekolah di pondok pesantren

3. Peluang menjadi TNI yang diberikan pihak pesantren kepada siswa biasa selain santri mondok menyebabkan orang tua merasa cukup belajar di madrasah di pagi hari

4. Pemahaman orang tua yang sangat awam tentang hiruk-pikuk kehidupan pesantren

5. Kesibukan orang tua yang menyebabkan turut serta bantuan anak dalam pekerjaan

6. Kurangnya kepercayaan orang tua untuk mengizinkan anak pulang pergi belajar di pesantren sore dan malam

Keenam faktor penyebab di atas, 3 faktor penyebab pertama berasal dari pihak pondok pesantren, dan 3 faktor terakhir berasal dari masyarakat. Akan tetapi menurut hemat peneliti, jika orang tua benar-benar mengenali kehidupan pesantren dan memahami manfaat dari pembelajaran salafiyah, masyarakat dusun Oli akan memiliki pertimbangan yang berbeda. Sebab orang tua masih meyakini bahwa semua pembelajaran di pesantren selalu memiliki nilai positif bagi anak sebagaimana penulis uraikan pada pandangan masyarakat tentang pembelajaran salafiyah di pondok pesantren Shuffah Hizbullah. Hal ini tentunya kembali kepada pihak pondok pesantren dalam mengambil langkah-langkah tertentu untuk memberikan pemahaman kepada masyarakat tentang pondok pesantren dan budayanya, sehingga masayarakat yang awam dengan kehidupan pesantren sebagaimana yang terjadi dalam masyararakat dusun Oli desa Hitu kecamatan Leihitu kabupaten Maluku Tengah ini dapat mengambil peran dan turut serta dalam mengembangkan pondok pesantren yang berdiri di daerahnya. 


\section{PEMBAHASAN}

\section{Sistem Pembelajaran Salafiyah di Pondok Pesantren Shuffah Hizbullah Dusun Oli Desa Hitu Kabupaten Maluku Tengah}

Sanjaya mengemukakan, berpikir dengan menggunakan pendekatan sistem memiliki daya ramal akan keberhasilan suatu proses. Artinya manakala semua komponen yang membentuk sistem itu bekerja secara proporsional, maka dipastikan tujuan yang telah ditentukan akan tercapai secara maksimal. Sebaliknya ketika komponen yang membentuk sistem itu tidak berkerja sesuai fungsinya, maka pergerakan sistem akan terganggu dan pada akhirnya akan menghambat ketercapaian tujuan (Sanjaya, 2010: 49-50). Hal ini menunjukkan betapa urgennya kerjasama setiap komponen dalam suatu sistem. Sekecil apapun komponen suatu sistem, jika tidak bekerja sesuai ketentuan, maka akan berpengaruh terhadap keberhasilan sistem tersebut.

Pembelajaran Salafiyah terdiri dari dua kata, yakni pembelajaran dan slafiyah. Pembelajaran adalah kegiatan yang dilakukan oleh guru dengan cara-cara tertentu agar peserta didik dapat belajar (Arsyad, 2017: 1) untuk mencapai tujuan pendidikan. Dengan kata lain, inti aktivitas pendidikan adalah pembelajaran (Helmiati, 2013: iii). Pembelajaran merupakan aspek utama yang menentukan kualitas pendidikan. Oleh karena itu untuk memecahkan masalah rendahnya kualitas pendidikan harus menengok kembali kualitas pembelajaran. Dalam konteks ini, yang menjadi fokus utama pembelajaran adalah guru. Profesionalitas (Syah, 229-234) seorang guru sangat menentukan baiknya kualitas pembelajaran.

Arti salafiyah berasal dari kata salaf yang berarti terdahulu, klasik, atau tradisonal. Jadi pembelajaran salafiyah dapat diartikan sebagai kegiatan belajar yang dilakukan oleh guru dengan peserta didik dengan menggunakan cara-cara tradisional untuk mencapai tujuan tertentu. Istilah pembelajaran salafiyah hanya ada dalam dunia pesantren, sebab pesantren yang masih mempertahankan model pembelajaran ulama-ulama terdahulu disebut pesantren salafiyah.

Pembelajaran salafiyah termasuk suatu sistem. Adapun komponen sistem pembelajaran meliputi tujuan, materi, metode/strategi, media, dan evaluasi.

\section{Tujuan pembelajaran salafiyah}


Tujuan adalah sasaran akhir dari sebuah kegiatan yang dilakukan. Ibarat jantung manusia, jika tidak berdetak, maka semua organ manusia akan kehilangan fungsinya. Sama halnya dengan tujuan pembelajaran.. Tujuan pembelajaran hendaknya disesuaikan dengan ketersediaan waktu, kesiapan siswa, keadaan sarana dan prasarana (Nata, 2009: 314).

Henry Ellington dalam Hamzah B. Uno mengemukakan bahwa tujuan pembelajaran merupakan pernyataan-pernyataan yang disusun dengan harapan dapat dicapai sebagai hasil belajar (Uno, 2010: 35). Sedangkan Oemar hamalik mengatakan, tujuan pembelajaran ialah sebuah deskripsi tentang tingkah laku yang diharapkan dapat dicapai oleh siswa setelah pembelajaran berlangsung (Hamalik, 2010: 109).

Dari hasil penelitian yang ditemukan di pondok pesantren Shuffah Hizbullah Dusun Oli terkait tujuan pembelajaran salafiyah ditemukan bahwa tujuan pembelajaran salafiyah adalah:

a. Menyiapkan santri untuk dapat membaca Al-Qur'an dengan baik dan benar dan menghafal minimal 3 juz.

Tujuan ini dirumuskan dengan pertimbangan bahwa santri yang masuk ke pondok pesantren Shuffah Hizbullah rata-rata belum benar bacaan AI-Qur'annya, bahkan ada yang belum tahu membaca Al-Qur'an (khusus reguler). Sehingga pelajaran pertama dan utama yang diberikan adalah memperbaiki dan memperindah bacaan Al-Qur'an santri. Selain itu juga, pelajaran ini menjadi modal utama bagi santri dalam mengikuti pembelajaran salafiyah yang lainnya yakni pembelajaran hadits dan tata bahasa Arab.

b. Menyiapkan santri untuk dapat memahami dasar-dasar syari'at Islam dengan menghafal minimal 40 hadits.

Tujuan ini ditetapkan dengan pertimbangan bahwa dasar-dasar syariat Islam merupakan masalah yang akan dialami santri dalam kehidupan sehari-hari. Sehingga pemahaman tentang dasar agama tersebut perlu ditanamkan dengan baik kepada santri, agar mereka tidak mengabaikan syari'at tersebut dan setelah kembali ke masyarakat, mereka dapat menyampaikan syariat tersebut di dalam kehidupan keluarga dan masyarakat nantinya. 
c. Menyiapkan santri untuk dapat memahami susunan tata bahasa Arab dengan menghafal salah satu dari kitab jurumiyah dan amsilatuttasrifiyah.

Tujuan ini diberikan dengan alasan karena materi tersebut tidak dipelajari dalam pendidikan formal dan non formal lain secara detail, sementara materi ini penting diajarkan agar santri dapat memiliki pengetahuan yang menunjang dalam memahami Al-Qur'an dan hadits.

Tiga tujuan pembelajaran di atas menggambarkan bahwa dalam menjalankan fungsinya sebagai pesantren salafiyah - di samping pesantren khalafiyah juga pondok pesantren mengharapkan santri yang lulus dari lembaga ini dapat memiliki kemampuan yang baik dalam membaca Al-Qur'an serta mampu menghafalnya minimal 3 juz, memiliki pengetahuan yang luas dalam bidang hadits, dan memiliki pengetahuan dasar tata bahasa Arab.

\section{Materi Pembelajaran Salafiyah}

Materi pembelajaran merupakan substansi, konten atau isi yang akan disampaikan kepada siswa/santri dalam proses pembelajaran. Tanpa adanya unsur ini, maka proses pembelajaran tidak akan berjalan. Oleh karena itu setiap guru yang akan mengajar pasti memiliki pemahaman dan penguasaan materi pelajaran yang disampaikan kepada siswanya.

Materi adalah sumber belajar bagi siswa, yang berisi pesan untuk mencapai tujuan pembelajaran (Pane, 2017: 2). Meteri pembelajaran merupakan unsur inti dalam kegiatan pembelajaran, karena unsur itu yang diupayakan untuk dikuasai oleh siswa. Oleh karena itu, guru ataupun pengembang kurikulum seyogiyanya harus memilikirkan sejauh mana bahan-bahan yang topiknya tertera yang berhubungan dengan kebutuhan siswa pada usia tertentu dan dalam lingkungan tertentu (Djamarah, 2006: 44).

Dalam pembelajaran salafiyah di pondok pesantren Shuffah Hizbullah terdapat tiga mata pelajaran yakni:

a. Pembelajaran Al-Qur'an

Istilah pembelajaran Al-Qur'an biasanya identik dengan belajar tafsir. Yakni mempelajari tafsir Al-Qur'an dan maknanya serta interpretasinya oleh para ulama tafsir. Namun dalam pembelajaran Al-Qur'an di sini, bukan mempelajari tafsir, melainkan tentang tata cara membaca Al-Qur'an. Sehingga materi yang diajarkan 
dalam pembelajaran ini meliputi masalah hukum bacaan/ilmu tajwid dan makharijul huruf. Sebab tujuan pembelajaran Al-Qur'an hanya mengarah pada kemampuan membaca al-Qur'an sesuai tajwid dan makharijul huruf, bukan untuk memahami makna Al-Qur'an.

b. Pembelajaran hadits

Pembelajaran hadits berisi materi dasar ibadah yang dimulai dari thaharah, materi shalat, materi jenazah, materi tentang sifat-sifat terpuji seperti ikhlas, taubat, sabar, jujur, takwa, dan lain-lain. Materi ini adalah materi yang bermanfaat bagi kehidupan sehari-hari, baik untuk hubungan manusia dengan tuhannya, maupun hubungan manusia dengan sesama makhluk.

C. Pembelajaran nahwu dan sharaf

Materi yang diajarkan dalam pembelajaran nahwu dan sharaf meliputi, kalam (kalimat) dan bagian-bagiannya seperti isim, fi'il, huruf serta tanda-tandanya, i'rab dan pembagiannya seperti rofa', nashab, harfud jer dan jazm, tanda-tanda i'rab, amil-amil (yang menyebabkan perubahan i'rab), serta sharaf meliputi tashrif, ishtilahi, dan lain sebagainya.

Materi yang diajarkan ini merupakan materi dasar dalam memahami tata bahasa Arab. Manfaat mempelajari materi ini adalah santri mampu mengimla' bacaan AlQur'an dan hadits, selain itu mereka bisa dapat memberi harakat dalam tulisan arab gundul. Dengan demikian dapat dikatakan juga bahwa ilmu ini bisa menjadi dasar bagi santri untuk membaca kitab kuning/kitab gundul.

\section{Metode/Strategi pembelajaran}

Metode adalah cara untuk mencapai sesuatu. Metode pembelajaran digunakan oleh guru untuk mencapai tujuan pembelajaran dengan menciptakan lingkungan belajar yang melibatkan siswa selama proses pembelajaran (Majid, 2014: 132). Metode pembelajaran dan teknik pembelajaran merupakan dua hal yang berbeda. Metode lebih bersifat prosedural yang berisi tahapan-tahapan, sementara teknik adalah cara yang dipilih oleh guru yang bersifat implementatif (Uno, 2011: 7). Dengan kata lain, metode yang dipilih oleh satu guru boleh jadi sama dengan metode yang dipilih oleh guru yang lain, namun teknik kemungkinan berbeda, tergantung pada apa yang diimplementasikan oleh gurunya. 
Metode pembelajaran dalam pendidikan pesantren ada yang bersifat tradisional, yakni pembelajaran yang dilakukan dengan menggunakan metode pembelajaran asli yang sudah menjadi kebiasaan sejak lama di dunia pesantren, dan metode tajdid, yaitu metode hasil pembaharuan pondok pesantren dengan memasukkan metode yang berkembang di masyarakat modern. Diantara metode pembelajaran tradisional pondok pesantren salafiyah adalah (Saifuddin, 2015: 207234):

a. Metode wetonan, yakni metode pembelajaran yang dilakukan dengan cara ustaz membaca kitab dan menerjemahkan serta menjelaskan isi kitab kepada santri, sementara santri menyimak dan menandai tanda pada kitabnya.

b. Metode sorogan, yakni pembelajaran dilakukan dengan cara santri mensorog (menyodorkan) kitabnya di hadapan kiyai atau pembantunya yang disebut badal. Metode ini termasuk dalam model pembelajaran individual, sebab satu santri berhadapan langsung dengan gurunya dan terjadi interaksi antara keduanya dan saling kenal mengenal.

c. Metode musyawarah atau bahtsul masa'il, yakni beberapa orang santri degan jumlah tertentu duduk membentuk halaqah yang dipimpin langsung oleh kiyai untuk mengkaji satu tema tertentu yang telah ditentukan. Dalam proses pembelajaran mengunakan metode ini, santri bebas mengajukan pertanyaan atau pendapatnya.

d. Metode hafalan, yakni santri diberi tugas menghafal bacaan tertentu dalam jangka waktu tertentu. Hafalan yang sudah dimiliki oleh santri akan disetorkan di hadapan kiyai secara periodik, tergantung pada petunjuk yang diberikan oleh kiyai.

e. Metode demonstrasi atau praktik, yakni pembelajaran dilakukan dengan memperagakan keterampilan tertentu dalam hal ibadah yang dilakukan secara individu maupun kelompok di bawah petunjuk dan bimbingan kiyai. Urutan kegiatan dimulai dari: a) santri diberi penjelasan tentang teori yag berisi tata cara ibadah yang akan dipraktikkan hingga santri paham, b) santri berdasarkan bimbingan Kiyai memoersiapkan kelengkapan yang dibutuhkan dalam kegiatan prakik, c) setelah menentukan tempat dan waktu, santri berkumpul dan menerima penjelasan singkat terkait urutan kegiatan yang akan dipraktekkan, d) santri 
secara bergiliran mempraktekkan tata cara ibadah dalam bimbingan kiyai, dan e) setelah selesai praktik, santri diberi kesempatan bertanya tentang hal-hal yang dipandang perlu selama kegiatan berlangsung.

Metode pembelajaran yang digunakan dalam proses pembelajaran salafiyah di pondok pesantren meliputi metode wetonan, hafalan, demonstrasi, penugasan dan latihan.

Dalam pembelajaran Al-Qur'an, metode yang digunakan adalah metode demonstrasi. Yakni santri mendemonstrasikan bacaan Al-Qur'an dengan AlQur'annya masing-masing di hadapan ustaz, kemudian akan diperbaiki bila terjadi kesalahan dalam bacaan santri. Metode ini sangat efektif dalam mempelajari bacaan al-Qur'an. sebab santri langsung membaca dan ustaz langsung perbaiki. jadi santri langsung memahami kesalahan dan cara membaca yang benar.

Bagi santri yang baru belajar membaca al-Qur'an, biasanya diajarkan oleh santri yang telah mahir dalam membaca al-Qur'an. Hal ini dilakukan agar santri tidak malu-malu dalam membaca karena diajarkan teman. Sementara santri yang sudah bisa membaca namun belum benar bacaannya ditangani langsung oleh ustaz. Metode ini digunakan dalam kegiatan tahsin al-Qur'an. Sementara dalam kegiatan tahfidz al-Qur'an, menggunakan metode hafalan, yakni santri menghafal al-Qur'an dan ustaz mendengar. Ketika terjadi kesalahan, langsung diperbaiki kembali. Kegiatan tahfidz ini dilakukan bagi santri yang sudah bisa membaca Al-Qur'an dengan baik dan benar.

Dalam pembelajaran hadits, metode yang digunakan oleh ustaz adalah metode wetonan. Yakni ustaz duduk di kursi dan meja, membaca kitab gundul, menerjemahkan, dan menjelaskan makna hadits, sementara santri mendengar semua penjelasan ustaz dan menandai pada kitabnya. Yang ditandai santri adalah terjemahan di bawah kata-kata yang tidak diketahui oleh santri. Sebab kitab yang dipegang santri adalah kitab yang sduah memiliki syakal. Setelah ustaz menjelaskan makna hadits secara menyeluruh, santri kemudian disuruh kembali membaca dan mnjelaskan makna hadits yang baru dijelaskan oleh sang ustaz. Dalam penjelasan santri, jika terjadi kesalahan maka langsung diperbaiki oleh ustaz. akan tepi, giliran membaca kembali ini tidak diberikan kesempatan kepada semua santri. hanya pada beberapa santri saja, sebagai ukuran bagi ustaz untuk mengecek santri telah paham 
atau belum. Hal ini tentunya kurang efektif, karena bisa jadi kemampuan memahami hadits antara satu santri akan berbeda dengan kemampuan santri yang lain.

Sedangkan dalam pembelajaran nahwu dan sharaf, metode wetonan juga diterapkan, ditambah dengan metode penugasan. Metode wetonan dilakukan dengan cara ustaz membaca kitab dan santri mengikuti kemudian ustaz mengartikan bacaan sementara itu santri menandai arti pada kitabnya masing-masing, kemudian ustaz menjelaskan serta memberi contoh. Dalam pembelajaran ini, ustaz biasanya membaca dan diikuti oleh santri hingga menghafalnya. Namun santri tidak diminta untuk menyetorkan hafalannya setelah pembelajaran nahwu sharaf ini.

Metode ini dalam praktiknya sama digunakan oleh semua ustaz, namun teknik yang digunakan oleh ustaz bereda-beda. Terutama dalam pembelajaran nahwu sharaf. Ada ustaz yang mengajar dengan suara datar saja, dan ada juga ustaz yang membaca dengan irama. Santri mengakui bahwa mereka sangat menyenangi suasana belajar dengan ustaz yang belajar menggunakan irama saat membaca kitab jurumiyah. Selain mudah diingat, santri merasa santai dan tidak tegang. Ustaz yang mengajar dengan irama ini adalah mereka yang datang dari jawa dalam rangka pengadian. Sementara teknik yang digunakan oleh ustaz dari internal pesantren dirasa sangat menegangkan. Ini berarti perlu adanya usaha penggantian teknik mengajar yang lebih menyenangkan para santri oleh para ustaz dari kalangan internal pondok pesantren Shuffah Hizbullah.

\section{Media pembelajaran salafiyah}

Media pembelajaran adalah alat bantu yang digunakan untuk memperlancar kegiatan pembelajaran agar tujuan pembelajaran dapat tercapai secara efektif dan efisien. Media pembelajaran dapat berupa makhluk hidup, benda-benda, dan segala sesuatu yang digunakan guru sebagai perantara dalam menyajikan materi pembelajaran. Media pembelajaran meiliki kelebihan dan kelemahan masingmasing. Oleh karena itu, perlu ada pertimbangan dalam memilih media yang sesuai, yakni:

a. Media harus sesuai dalam mencapai tujuan pembelajaran tertentu

b. Pendidik memahami dengan baik fungsi media pembelajaran yang digunakan serta dapat memanfaatkannya sesuai dengan materi dan tujuan pembelajaran yang telah ditetapkan 
c. Siswa dapat menerima dengan baik penggunaan media pembelajaran sesuai dengan kondisi dan latar belakang usia dan bakat-bakatnya.

d. Media pembelajaran harus memberikan dampak atau hasil yang baik kepada siswa serta tidak menimbulkan dampak negatif terhadap perkembangan akhlak, maupun perkembangan fisik dan psikisnya (Pane, 2017: 2).

Dalam pembelajaran hadits, media atau alat yang digunakan di pondok pesantren Shuffah Hizbullah adalah kitab Bulughul Maram dan Riyadhusshalihin. Dua kitab ini diajarkan secara bergantian. Tidak diajarkan sekaligus satu persatu, namun bergantian tergantung pada keinginan ustaz dalam mengajarkan kitab. Akan tetapi kitab yang awal diajarkan adalah kitab bulughul maram tentang dasar-dasar ibadah, setalah itu bergantian dengan kitab riyadhussalihin. Sementara media pembelajaran AI-Qur'an hanya menggunakan AI-Qur'an satu-satunya.

Untuk pembelajaran nahwu dan sharaf, bahan yang digunakan adalah kitab jurumiyan dan amsilatuttasrifiyah. Kedua kitab ini juga diajarkan secara bergantian tergantung pada yang diinginkan pengajar. Selain menggunakan kedua kitab tersebut, papan tulis dan spidol juga digunakan ustaz dalam menjelaskan dan memberikan contoh isi kitab jurumiyah dan amsilatuttasrifiyah.

Mukhtaruddin mengemukakan, ketentuan bagi lulusan pondok pesantren dan pendidikan diniyah yang legal yang telah ditetapkan oleh Dirjen Kelembagaan Agama Islam Nomor: Dj.11.11/V/PP.007/AZ/28/04 tanggal 9 Januri 2004 dan Dirjen Pendidikan Islam dilakukan melalui prosedur dan syarat-syarat yang telah ditetapkan, salah satunya yaitu kitab-kitab kuning yang dipelajari serendahrendahnya mencakup semua bidang studi dan acuan kitab-kitabnya dan/atau yang sederajat isinya sebagai berikut (Magelang, 2011: 164):

a. Tingkat Dasar/MI dan sederajat (1) Al-Qur'an: Khatam 30 juz binnadar dengan tajwid yang bagus; (2) Tauhid: 'Aqidat al-'Awam/Umm alBaroohim; (3). Fiqih: Safinat al-Najah/Sullam at-Taufiq; (4) Akhlak: Al-Akhlaaku li al-Baniin/Banat; (5) Nahwu: Al-Jurumiyah/Nadzom al-Imriti; dan (6). Sharaf: Matan al-Bina wa alAsas/Al-Amtsilati atTashrifiyah.

b. Tingkat Menengah Pertama/SPT/MTs (1) Al-Qur'an: Hafal juz 30 dengan tajwid yang bagus; (2) Tauhid: Kifaayatu al-'Awam/Al-Sanusiyah; (3) Fiqih: Fath alQorib/Kifaayat al-Akhyar; (4) Akhlak: Bidayatu al-Hidayah/Ta'lim al-Muta'alim; (5) Nahwu: Mutammimah/Al-Asymawi; (6) Shoraf: Nadzom al-Maqsud/Al-Kailani; (7) Tarikh: Nur al-Yaqin; dan (8) Tajwid: Hidayat al-Mustafidz/At-Tibyan fi Hamalat alQur'an. 
c. Tingkat Menengah Atas/SMA/MA (1) Tafsir: Jalalain; (2) IIm Tafsir: Mabahits fi 'Ulum al-Qur'an/Al-Itqon; (3) Hadits: Riyad as-Sholihin/ Bulugh al-Maram; (4) IImu Hadits: Al-Baiquniyyah/Al-Manhal alLathief; (5) Fiqih: Fath al-Mu'in/l'anat atTholibin/ Muhadzdzab; (6) Ushul Fiqih: Al-Waraqat/Al-Luma'/Al-Asybah wa anNadzoir; (7) Tauhid: Al-Husun al-Hamidiyyah/Al-Milal wa an-Nihal; (8) Nahwu: Alfiyah Ibnu Malik/Syarh Ibn Aqil; (9). Sharaf: Al-I'lal/Qowa'id alLughoh alArobiyyah; (10) Tarikh: Ismam al-Wafaq/Tarikh Tasyri'; dan (11) Balaghoh: AlJauhar al-Makmun.

Mengacu pada peraturan dirjen diatas, menunjukkan bahwa setiap tingkatan santri di pondok pesantren seharusnya berbeda dalam mengkaji kitab kuning. Tingkat penguasaan Al-Qur'an juga berbeda. Santri yang memulai dari tingkat dasar (MI/SD) memiliki pengusaan kitab dengan santri setingkat di atasnya (MTs/SMP), begitu pula tingkat SMP akan berbeda penguasaannya dengan MA dan SMA.

Di pondok pesantren Shuffah Hizbullah, pengkajian kitab kuning tidak dibedakan antara tingkat wustha dan tingkat aliyah. Keduanya sama-sama mempelajari kitab bulughul maram, riyadhusshalihin, jurumiyah dan amsilatuttasrifiyah. Jika diamati pada peraturan Dirjen di atas, maka kitab jurumiyah dan amsilatuttasrifiyah yang seharusnya dipelajari di tingkat dasar (MI) diajarkan di tingkat wustha dan aliyah. Hal ini karena santri yang belajar di pesantren Shuffah Hibullah belum pernah mempelajari kitab itu sebelumnya. Sehingga meskipun santri masuk di tingkat wustho ataupun aliyah, tetap mempelajari dasar tata bahasa Arab melalui kitab ini.

Sedangkan untuk pembelajaran hadits, wustha dan aliyah juga sama-sama mempelajari kitab riyadhussalihin dan bulughul maram. Padahal pada peraturan di atas, pembelajaran hadits hanya untuk santri tingkat aliyah. Hal ini dilakukan pondok pesantren karena santri wustho juga penting mempelajari kitab tersebut, sebab pada usia mereka, meski tidak semuanya, ada yang sudah baligh dan dikenakan hukum wajib beribadah (tamyiz). Kalaupun ada yang belum tamyiz, pelajaran ini bisa jadi bekal untuk mereka ketika sudah tamyiz.

Dengan demikian dapat dikatakan bahwa santri yang memulai sekolah di pesantren dari tingkat wustha sampai ke tingkat aliyah, akan memiliki banyak pemahaman agama dan tata bahasa Arab melalui ke empat kitab di atas. Akan tetapi jika dimulai dari tingkat aliyah saja, maka ilmu yang didapatkan santri tidak cukup anyak. 


\section{Evaluasi pembelajaran}

Evaluasi adalah komponen terakhir sistem pembelajaran. Evaluasi dilakukan untuk mengetahui kekurangan dalam pemanfaatan berbagai komponen dalam pembelajaran. Dengan melakukan evaluasi di akhir pembelajaran, guru dapat mengetahui sejauh mana pemahaman materi yang dicapai oleh siswa selama mengikuti pembelajaran. Ketiadaan proses evaluasi, maka guru, siswa, orang tua/wali serta lembaga tidak mungkin mengetahui hasil yang diperoleh dari pembelajaran yang telah dilaksanakan. Oleh karena itu, evaluasi sangat urgen dalam proses belajar mengajar (Sanjaya, 2010: 61).

Peraturan Menteri Pendidikan Nasional No. 49/ 2007 tentang Standar Pengelolaan Pendidikan oleh Satuan Pendidikan Nonformal pada Pasal 1 ayat 2 poin c Tentang Pengawasan Dan Evaluasi disebutkan bahwa satuan pendidikan nonformal perlu menetapkan indikator untuk menilai kinerja dan melakukan perbaikan dalam rangka mencapai standar nasional pendidikan, sehingga satuan pendidikan nonformal harus melakukan:

a. Evaluasi proses pembelajaran secara periodik sesuai dengan program yang diselenggarakan.

b. Evaluasi program kerja tahunan secara periodik sekurang-kurangnya satu kali dalam setahun.

c. Evaluasi diri program yang diselenggarakan satuan pendidikan nonformal dilakukan secara periodik dan berkelanjutan (Putra, 2013).

Sebagai pondok pesantren kombinasi, evaluasi pada pembelajaran khalafiyah telah dilakukan sebagaimana mestinya, namun evaluasi dalam pembelajaran salafiyah belum dilakukan secara baik dan sistematis.

Untuk pembelajaran hadits, tujuan yang dirumuskan seperti santri dapat memahami dasar-dasar syariat Islam dengan menghafal minimal 40 hadits tidak dilakukan evaluasi untuk mengukur keberhasilan tujuan tersebut. Baik secara periodik maupun tahunan. Dalam perencanaannya pimpinan pondok merencanakan bahwa ada setoran hafalan hadits setiap tahun sebelum memasuki bulan ramadhan. Namun kenyataannya kegiatan evaluasi tersebut belum terlaksana. meskipun terlaksana, cara evaluasi dengan menyetor hafalan hadits belum tentu sudah mewakili pamahaman santri dalam memahami hadits. sebab menghafal tidak sama dengan memahami. selain itu juga, jika diberlakukan satu tahun sekali baru ada penyetoran hafalan hadits, maka ini adalah waktu yang lama untuk melakukan evaluasi terhadap kegiatan yang setiap minggu diadakan dua kali. Hal ini akan lebih efektif jika evaluasi pemahaman hadits dilakukan setiap pembahasan satu bab atau 
kurung waktu semester tertentu. Sebab mengukur kemampuan pemahaman terhadap materi yang banyak sekaligus dalam kurung waktu satu tahun sulit diingat kembali oleh santri. Apalagi di pesantren ini, santri juga belajar di madrasah. Hal ini akan sulit bagi santri.

Selanjutnya dalam pembelajaran nahwu sharaf yang bertujuan agar santri mampu memahami susunan tata bahasa Arab dengan menghafal minimal salah satu dari kitab jurumiyah dan amsilatuttasrifiyah dilakukan evaluasi tiap semester untuk mengetahui pemahaman santri tentang materi yang telah dipelajari. Akan tetapi tidak dilakukan evaluasi untuk menguji hafalan kitab jurumiyah atau amsilatuttasrifiyah. Tugas-tugas yang diberikan kepada santri untuk mengulang di asrama juga tidak diperiksa kebenaran dan kesalahannya, tugas diberikan hanya sebatas untuk latihan bagi santri. Hal ini menunjukan bahwa evaluasi untuk mengukur tujuan pembelajaran nahwu sharaf juga tidak bisa terukur semuanya. Pemahaman diukur, namun hafalan tidak diukur.

Kenyataan di atas kemudian berdampak pada dua hal, yakni pada minat dan kesungguhan belajar santri selama belajar salafiyah di pondok pesantren dan berdampak pada kualitas lulusannya. Dikatakan berdampak pada minat belajar santri adalah ketika santri melihat tidak adanya evaluasi yang serius terhadap pembelajaran, maka kesungguhan mereka dalam belajar juga berkurang, sebab tidak ada ukuran lulus atau tidak. Di satu sisi, tugas hafalan hadits atau tugas susunan bahasa Arab yang diberikan tidak diperiksa lagi kebenaran dan penguasaan santri terhadap pembelajaran itu tentu akan ada santri yang menjadi tidak serius mengikuti pembelajaran tersebut. Apalagi tidak ada hukuman bagi mereka yang melanggar atau hadiah bagi mereka yang telah mencapai atau melebihi target pembelajaran yang telah ditetapkan.

Selanjutnya tidak adanya evaluasi yang sistematis berdapak pada kualitas lulusan yang mengikuti pembelajaran salafiyah di pondok pesantren Shuffah Hizbullah. Lulusan yang ditentukan harus memahami dan menghafal minimal 40 hadits akhirnya bisa lulus dengan menghafal kurang dari 10 hadits. Soal pemahaman, tidak bisa diukur, karena paham tidaknya santri terhadap hadits hanya akan dirasakan oleh santri masing-masing. Begitu pula dengan pembelajaran nahwu dan sharaf. Karena ukuran pemahaman juga tidak diukur, akhirnya ada santri yang 
lulus dengan bisa mengimla' al-Qur'an dan hadits, dan ada pula yang belum mampu untuk melakukannya, apalagi sampai menghafal 1 kitab jurumiyah atau amsilatuttasrifiyah, belum ada lulusan yang memiliki kemampuan ini.

Dari uraian komponen sistem pembelajaran salafiyah di atas, dapat disimpulkan bahwa pembelajaran salafiyah di pondok pesantren Shuffah Hizbullah dalam pelaksanaannya belum sesuai dengan tata cara kerja sistem. Meskipun pembelajaran ini memiliki tujuan, materi, metode, media, dan evaluasi, namun masing-masing komponen belum difungsikan secara maksimal. Terutama komponen evaluasi. Padahal komponen ini yang melihat ketercapaian tujuan melalui kinerja komponen materi, metode dan media. Karena komponen evaluasi tidak difungsikan dengan baik, maka berdampak pada kekurangefektifan pondok pesantren Shuffah Hizbullah dalam mencapai tujuan pembelajaran salafiyah.

\section{Hasil Pembelajaran Salafiyah}

Tujuan pendidikan pesantren sebagaimana yang dutarakan oleh Zamaksyari Dzofier:

"Tujuan pendidikan tidak semata-mata untuk memperkaya fikiran murid dengan penjelasan-penjelasan, tetapi untuk meninggikan moral, melatih dan mempertinggi semangat, menghargai nilai-nilai spiritual dan kemanusiaan, mengajarkan sikap dan tingkah laku yang jujur dan bermoral, dan menyiapkan para murid untuk hidup sederhana dan bersih hati. Setiap murid diajar agar menerima etika agama di atas etik-etik yang lain. Tujuan pendidikan pesantren bukanlah untuk mengejar kepentingan kekuasaan, uang dan keagungan duniawi, tetapi ditanamkan kepada mereka bahwa belajar adalah semata-mata kewajiban dan pengabdian kepada Tuhan" (Syamsu, 2011: 95112).

Dari tujuan tersebut, dapat diartikan bahwa lulusan pondok pesantren sudah pasti memiliki kemampuan dalam menguasai ilmu agama, memiliki akhlak yang baik serta memiliki pegangan kuat dalam menjalankan kehidupan di dunia ini. Dalam perkembangannya, ada pondok-pondok pesantren yang mengkhusukan atau memfokuskan pembelajarannya pada satu sasaran tertentu, seperti penguasaan kitab kuning, penguasaan bahasa Arab, penguasaan bahasa Inggris, hafalan AlQur'an dan lain sebagainya. Dengan adanya fokus pada satu kualitas tertentu, maka lulusan yang keluar dari pondok pesantren itu tidak diragukan lagi keilmuannya pada bidang yang mereka tekuni. Apalagi selain berfokus pada kajian tertentu, santri yang belajar di pondok pesantren juga dibekali dengan keterampilan-keterampilan tertentu 
seperti karate, silat, berpidato/ceramah, bertani, beternak dan lain sebagainya. Dengan adanya tambahan kegiatan ekstra tersebut, lulusan pondok pesantren pada akhirnya memiliki multi keterampilan. Lulusan ini bisa tercetak mana kala pondok pesantren tempat belajar santri tersebut benar-benar menjalankan fungsi pembelajarannya dengan maksimal. Artinya baik tidaknya kualitas lulusan dari pondok pesantren, tergantung pada kualitas pendidikan dan pengajaran yang dilakukan dalam pokndok pesantren tersebut.

Lulusan pondok pesantren yang dapat diamati kualitasnya adalah ketika santrinya mampu berbahasa Arab atau Inggris, atau mampu membaca kitab kuning/kitab gundul, mampu menguasai tata bahasa Arab dan inggris, mampu berpidato, serta kemampuan menghafal Al-Qur'an dan hadits. Kualitas lulusan tersebut tengantung pada pesantren dengan fokus pembelajarannya.

Kualitas alumni pondok pesantren Shuffah Hizbullah dapat dilihat pada kemampuan santri dalam berceramah, baik berceramah karena tugas sebagai binroh, sebagai penceramah dalam kegiatan tertentu di sekolah, maupun ceramah pada bulan ramadhan di kampung halaman tempat tinggal alumni. Selain itu, ada juga masyarakat yang mengagumi akhlak lulusan pesantren yang dirasa berbeda dan lebih baik dari anak atau remaja yang ada di kampung mereka. Akhlak yang ditunjukkan berupa kesopanan yang mereka tunjukkan, cara berpakaian yang sopan dan menutup aurat, kemudian para alumni juga mengabdikan ilmunya dengan membuka taman pengajian Al-Qur'an di Dusun Liaela.

Kemampuan yang dimiliki oleh lulusan di atas adalah bentuk keberhasilan dari pembelajaran hadits dan kegiatan ekstra muhadharah yang dilaksanakan dalam program salafiyah pesantren, dimana para santri dilatih untuk berpidato dua hari sekali dalam seminggu. Selain itu program pembelajaran salafiyah lainnya adalah tahsin dan tahfidz Al-Qur'an, dimana santri diperbaiki bacaan Al-Qur'annya, mulai dari yang tidak tahu membaca Al-Qur'an hingga mampu membaca bahkan menghafal Al-Qur'an dengan baik dan benar sesuai hukum bacaan dan makharijul hurufnya. Program tersebut menjadi bekal besar kepada alumni setelah kembali ke kampung halamannya, yakni dengan membuka taman pengajian al-Qur'an untuk mengajarkan anak-anak di kampunya yang belum tahu membaca al-Qur'an. 
Hasil belajar nahwu sharaf tidak terlihat saat alumni kembali ke kampung halamnnya. Kemampuan dalam idang ini akan muncul dan dirasakan manfaatnya sendiri oleh alumni ketika mengikuti tes-tes tertentu yang mensyaratkan kemampuam imla' atau kemampuan memberi syakal pada huruf gundul. Karena itu, jika terlihat aplikasinya dalam kehidupan sehari-hari, jelas tidak tampak.

Meski telah tampak hasil pembelajaran salafiyah dari lulusan pondok pesantren, namun masih ada harapan alumni agar pesantren bisa lebih maju lagi dalam menjalankan sistem pembelajaran salafiyah. Yakni pembelajaran hadits ditingkatkan lagi dengan kemampuan membaca kitab kuning, sementara pembelajaran nahwu sharaf ditingkatkan lagi menjadi kemampuan berahasa Arab. Selain itu juga alumni berharap agar tujuan pembelajaran yang telah ditetapkan benar-benar harus dievaluasi setelah santri mengikuti pembelajaran. Agar santri benar-benar bersunguh-sungguh untuk belajar salafiyah, dan tidak menganggap enteng pembelajaran tersebut. Karena pembelajarn tersebut memiliki banyak manfaat kelak ketika mereka telah lulus.

\section{Pembelajaran Salafiyah dalam Pandangan Masyarakat}

Keberadaan pondok pesantren pada dasarnya tidak dapat dilepas pisahkan dengan masyarakat. Pondok pesantren hadir karena masyarakat dan berkemang karena masyarakat. Pengaruh masyarakat terhadap pondok pesantren bisa berpotensi baik untuk pengembangan pondok pesantren dan sebaliknya bisa menjadi penghambat bagi perkambangan pesantren. Berpotensi baik untuk pengembangan, manakala pondok pesantren tanggap terhadap tuntutan kebutuhan masyarakat. Sebaliknya berpotensi menghambat apabila pesantren tidak respek terhadap kebutuhan masyarakat tersebut.

Dengan kompleksnya permasalahan yang dihadapi oleh masyarakat saat ini, justru kehadiran pesantren menjadi solusi di tengah-tengah kegamangan lembaga pendidikan lainnya. Dengan demikian, maka kehadiran pesantren bukan untuk mengabaikan aspirasi masyarakat, namun hadir untuk menghidupkan potensipotensi dasar yang telah dimiliki oleh masyarakat, pesantren melanyelenggarakan pendidikannya untuk melanggengkan nilai-nilai yang hidup dalam masyarakat itu sendiri. Dengan keikutsertaan masyarakat dalam pengelolaan pendidikan pesantren, 
maka akan memberikan fungsi pendidikan yang berakar dari masyarakat (Wekke, 2012: 205-226).

Agar terjalin hubungan baik antara masyarakat dan pondok pesantren, maka perlu ada komunikasi dan kerja sama antara pondok pesantren dengan masyarakat. Ketika terjalin kerjasama antara kedua elemen tersebut, tentu masyarakat akan mengemukakan keinginan atau aspirasi-aspirasinya dan pesantren menjalankan programnya untuk memenuhi aspirasi tersebut. Dan dalam perkembangannya, untuk memajukan kualitas pondok pesantren, tentu masyarakat akan dilibatkan untuk mengevaluasi kelemahan-kelemahan yang dihadapi secara bersama-sama.

Peran dan fungsi pesantren dalam masyarakat yang disebutkan dalam mukernas ke V Rabithah al-Ma'hid al-Islamiah di Probolinggo tahun 1996, meliputi (Muhakamurrohman, 2014: 109-118):

1. Sebagai lembaga pendidikan dan pengajaran Islam, dalam arti pesantren juga mengambil tanggung jawab dalam mencerdaskan kehidupan bangsa dengan mempersiapkan sumberdaya manusia yang cerdas, kompetitif dengan dilandasi keimanan dan ketakwaan yang kokoh.

2. Sebagai lembaga perjuangan dan dakwah islamiyah, berarti pondok pesantren bertanggungjawa dalam menyiarkan agama Allah serta ikut berpartisipasi aktif dalam membangun kehidupan ummat beragama serta meningkatkan kerukunan umat beragama dalam kehidupan bermasyarakat, berbangsa dan bernegara.

3. Sebagai lembaga pemberdayaan dan pengabdian masyarakat, berarti pondok pesantren memiliki kewajiban merealisasikan peran dan fungsi serta emansipasi yang dimilikinya gunan memperbaiki kehidupan serta memperkokoh tiang keberadaan masyarakat demi terwujudnya masyarakat Indonesia yanga adil, beradab, sejahtera dan demokratis.

Sejak awal berdirinya, pondok pesantren Shuffah Hizbullah telah menjalankan perannya lembaga pendidikan dan pengajaran Islam, baik secara formal maupun non formal. Secara formal, pondok pesantren memuka madrasah Aliyah dan program Wustha (Setara SMP dan MTs) serta program tahfidz AI-Qur'an. 
Untuk program aliyah dan wustha, mengikuti pembelajaran dan ujian layaknya madrasah pada umumnya. Sedangkan program tahfidz Al-Qur'an memfokuskan hafalan Al-Qur'an selama 2 tahun kemudian di tahun terakhir bergabung bersamasama kelas reguler (aliyah/wustha) untuk belajar persiapan ujian akhir nasional. Sehingga program tahfidz pun isa mendapatkan ijazah layaknya anak reguler.

Pendidikan formal yang dijalankan di pondok pesantren dilakukan melalui sosialisasi dalam bentuk pembagian brosur. Sehingga masyarakat yang mendapat brosur bisa mengetahui tingkat pendidikan serta sarana dan prasarana yang dimiliki oleh pondok pesantren.

\section{KESIMPULAN}

Bertolak dari pembahasan di atas, dapat disimpulkan bahwa Sistem pembelajaran salafiyah di pondok pesantren Shuffah Hizbullah dilakukan secara tradisional dan belum terlaksana secara maksimal, karena komponen evaluasi seagai komponen paling urgen dalam mengukur ketercapaian tujuan pemelajaran tidak dilksanakan secara konsisten dan sistematis. Hal ini kemudian berdampak pada kurangnya kesugguhan seagian santri dalam mengikuti pemelajaran salafiyah. Secara umum masyarakat Dusun Oli sangat menyukai sistem pemelajaran salafiyah di pondok pesantren Shuffah Hizbullah, hanya saja masyarakat yang menyekolahkan anaknya di sini tidak memahami apa yang dipelajari dalam pembelajaran salafiyah karena minimnya sosialisasi dan kerjasama pondok pesantren dengan masyarakat tempat pondok pesantren ini berdiri. Selan dari kurangnya pengetahuan terseut, program yang ditawarkan kepada santri mondok untuk menjadi TNI dibuerikan kepada siswa biasa yang tidak mengikuti pembelajaran salafiyah mengakiatkan orang tua merasa cukup elajar di madrasah saja. dengan demikian, dari hasil penelitian ini Pondok pesantren perlu memanage kembali sistem yang dijalankan di pondok pesantren Shuffah Hizbullah, sehingga masyarakat mengenal dekat dan memahami program yang dijalankan pondok pesantren dan ikut serta dalam memajukan pondok pesantren ke depan.

\section{DAFTAR PUSTAKA}


[1] Arikunto, Suharsimi (2010). Prosedur Penelitian; Suatu Pendekatan Praktik. Cet. XIV; Jakarta: Rineka Cipta.

[2] Arsyad, Azhar (2017). Media pembelajaran. Jakarta: Raja Grafindo Persada.

[3] Dhofier, Zamakhsyari (1997). Tradisi Pesantren: Studi tentang Pandangan Kyai.. Jakarta: LP3ES.

[4] Djamarah, Syaiful Bahri (2006). dan Aswan Zain. Strategi Belajar Mengajar. Jakarta: Rineka Cipta.

[5] Ghazali, M. Bahri (2001). Pendidikan Pesantren Berwawasan Lingkungan: Kasus Pondok Pesantren An-Nuqayah Guluk-Guluk Sumenep, Madura .Jakarta: Pedoman IImu.

[6] Hamalik, Oemar (2010). Perencanaan Pengajaran Berdasarkan Pendekatan Sistem. Jakarta: Bumi Aksara.

[7] Hasbullah (1996). Kapita selekta Pendidikan Islam.Cet. I; Jakarta: Raja Grafindo Persada.

[8] Helmiati (2013). Micro Teaching; Melatih Keterampilan Dasar Mengajar. Yogyakarta: Aswaja Pressindo,

[9] Magelang. P. P. A. P. I., \& Kaliwungu, P. A. F., (2011). Penguasaan Kitab Kuning. Analisa, 18(02), 164.

[10] Majid, Abdul (2014). Belajar dan Pembelajaran Pendidikan Agama Islam. Bandung: Remaja Rosdakarya.

[11] Mastuhu (1994). Dinamika Pendidikan Pesantren: Suatu Kajian Tentang Unsur dan Nilai Sistem Pendidikan Pesantren. Jakarta: INIS.

[12] Muhakamurrohman, Ahmad (2014). "Pesantren: Santri, kiai, dan tradisi." IBDA: Jurnal Kajian Islam Dan Budaya 12.2: 109-118.

[13] Nata, Abuddin (2009). Perspektif Islam Tentang Strategi Pembelajaran. Jakarta: Kencana.

[14] Nata, Abuddin (2016). Inovasi Pendidikan Islam. Jakarta: Salemba Diniyah.

[15] Pane, Apride. dan M. Darwis Dasopang (2017), Belajar dan pembelajaran. Fitrah. Jurnal IAIN Padang Sidimpuan, Vol.3 No. 2.

[16] Putra, Vivit Nur Arista (2013). "Manajemen Pembelajaran Di Pondok Pesantren Takwinul Muballighin Yogyakarta." hanata widya 2.4 
[17] Sanjaya, Wina (2010). Strategi Pembelajaran Berorientasi Standar Proses Pendidikan. Cet. VII; Jakarta: Prenada Media Group.

Sugiyono (2010) . Memahami Penelitian Kualitatif . Cet. VI; Bandung: Alfabeta.

[19] Saifuddin, Ahmad (2015). Eksistensi Kurikulum Pesantren dan Kebijakan Pendidikan, Jurnal Pendidikan Agama Islam,. 3 (1), 207-234.

[20] Sukmadinata, Nana Sayodih (2011). Metode Penelitian Pendidikan. Cet. VII; Bandung: Remaja Rosda Karya.

[21] Syah, Muhibbin (2010). Psikologi Pendidikan dengan Pendekatan Baru. Bandung: Remaja Rosdakarya.

[22] Syamsu, Rizal Ahmad (2011). Transformasi corak edukasi dalam sistem pendidikan pesantren, dari pola tradisi ke pola modern. Jurnal pendidikan agama islam-ta'lim, 9(2), 95-112.

[23] Trianto (2011). Pengantar Penelitian Pendidikan bagi Pengembangan Profesi Pendidikan dan Tenaga Kependidikan. Jakarta: Prenada Media Group.

[24] Uno, Hamzah B (2010). Perencanaan Pembelajaran. Jakarta: Bumi Aksara.

[25] Uno, Hamzah B. dan Nurdin Mohamad (2011). Belajar dengan Pendekatan PAILKEM. Jakarta: Bumi Aksara.

[26] Wekke, Ismail Suardi (2012). "Pesantren dan pengembangan kurikulum kewirausahaan: Kajian pesantren roudahtul khuffadz sorong papua barat." Inferensi: Jurnal Penelitian Sosial Keagamaan 6.2 :205-226.

[27] Yatim, Badri (2010). Sejarah Peraban Islam. Jakarta: Raja Grafindo Persada. 